\title{
Mould-based surface high-dose-rate brachytherapy for eyelid carcinoma
}

\author{
Andrea Vavassori, MD!, Giulia Riva, MD!2, Stefano Durante, MD!2, Cristiana Fodor, MScl, Stefania Comi, MSc', \\ Raffaella Cambria, MSc33, Federica Cattani, MSc ${ }^{3}$, Giuseppe Spadola, MD4, Roberto Orecchia, MD5, \\ Barbara Alicja Jereczek-Fossa, MD, PhD',2 \\ 'Department of Radiotherapy, IEO European Institute of Oncology IRCCS, Milan, Italy, ${ }^{2}$ Department of Oncology and Hemato-oncology, \\ University of Milan, Milan, Italy, ${ }^{3}$ Unit of Medical Physics, IEO European Institute of Oncology IRCCS, Milan, Italy, ${ }^{4}$ Melanoma, Sarcoma and \\ Rare Tumors Surgery Department, IEO European Institute of Oncology IRCCS, Milan, Italy, ${ }^{5}$ Scientific Directorate, IEO European Institute \\ of Oncology IRCCS, Milan, Italy
}

\begin{abstract}
Purpose: To evaluate toxicity and clinical outcomes in patients with eyelid tumour treated with contact high-doserate brachytherapy (HDR-BT).

Material and methods: Between April 2010 and August 2017, 10 consecutive patients with tumour of the eyelid underwent contact HDR-BT and custom-made surface mould. Every applicator was manually built using conventional thermoplastic material and standard plastic catheters. The median dose prescribed was 42 Gy (range, 30-48) with a median dose per fraction of 3.5 Gy (range, 2-4.5). The dose was delivered in a median of 12 fractions (range, 10-17) over a median of 16 days. In all cases, an ocular shield was placed to reduce the dose to the eye. Acute and late toxicity was evaluated according to RTOG toxicity criteria.

Results: We analyzed data of 9 of 10 patients (one patient was excluded because he did not give consent for investigation). The median age was 68 years (range, 31-88). According to the TNM-UICC staging system, 4,1 and 4 patients were stage IA, IB and IC, respectively. Basal cell and sebaceous gland carcinomas were reported in 5 and 2 patients, respectively; other histological types were non-Hodgkin lymphoma and plasmacytoma. After a median follow-up of 51 months (range, 16-90), there was no evidence of local or distant recurrence. The treatment was very well tolerated. Most commonly acute reactions consisted of low grade (G1-G2) conjunctivitis and skin erythema. Only one patient required a temporary interruption of the treatment due to acute G2 conjunctivitis and G3 lid erythema. Only one G2 late toxicity was reported (corneal ulceration), without resulting in functional impairment or blindness.

Conclusions: Our results suggest that contact HDR-BT with a customized applicator is safe, effective and offers very good local control and can be considered for the treatment of eyelid tumours.

J Contemp Brachytherapy 2019; 11, 5: 443-448 DOI: https://doi.org/10.5114/jcb.2019.88619
\end{abstract}

Key words: HDR, brachytherapy, eyelid, HDR-BT.

\section{Purpose}

Eyelid tumours are relatively uncommon, representing $<3-5 \%$ of all skin cancers in the head and neck region with an incidence of 15 cases per 100,000 individuals per year. They typically occur in the lower lid (50-66\%) and inner canthus $(25-30 \%)$.

Basal cell carcinoma (BCC) is the commonest histological type, representing about $85-90 \%$ of all cases, while squamous cell carcinoma (SCC) usually accounts for 2-9\% of eyelid malignancies. Sebaceous gland carcinoma (SGc), Merkel cell carcinoma and malignant melanoma are rare and generally affect the upper lid $[1,2,3,4,5]$.
A multidisciplinary team must collaborate in planning management of eyelid tumour.

The aim of treatment is definitive tumour control with functional preservation of anatomical structures. Surgery, wide excision or Mohs micrographic surgery is considered the gold standard with a high local control rate. Mohs micrographic surgery has been advocated for eyelid malignancies to ensure maximal preservation of normal tissue and to obtain margins free of disease. Orbital exenteration is necessary only in cases of locally advanced tumours with invasion of orbital structures $[6,7,8,9,10]$. 
Ophthalmic radiotherapy (RT) could be used as a curative therapy for small tumours, as adjuvant treatment after suboptimal surgical excision (with close or positive margins) or as palliative therapy for advanced and symptomatic lesions.

External beam radiotherapy (EBRT) and brachytherapy (BT) could represent a good alternative to surgery in particular when surgery may result in severe dysfunction of the lacrimal apparatus or in patients unfit because of comorbidities [11,12,13,14,15,16,17,18,19,20,21,22].

Brachytherapy can be delivered by superficial (with dedicated commercial or customized applicators) $[23,24,25,26,27,28]$ or interstitial application (with hypodermic needles or catheters) $[29,30,31,32]$.

Compared to EBRT, the main advantages of BT include a higher localised dose around the target volume with relative sparing of critical normal tissues. BT can be administered by a radioactive source using a low-doserate (LDR) or a high-dose-rate (HDR) modality or by electronic BT $[33,34,35]$.

The 3D optimization permits an increase of tumour coverage and a decrease of the dose to the organs at risk (OARs). The aim of this retrospective single-centre study is to evaluate long-term results and treatment-related toxicities of superficial HDR BT for eyelid carcinoma.

\section{Material and methods}

\section{Patient characteristics}

The inclusion criteria were as follows: 1) patients treated with exclusive HDR-BT for primary eyelid cancer between April 2010 and August 2017; 2) multidisciplinary tumour board to confirm the treatment strategy; 3) written informed consent for the use of their anonymized data and images for research and educational purposes.

This study was part of a research project notified to our Institutional Ethical Committee (notification 726).

Patients' evaluation included complete medical history and physical examination. Careful palpation of the lesion allows evaluation of induration and attachment to periorbital structures.
An ultrasound or a CT scan was performed in case of suspected regional lymph nodes or orbital involvement. For each patient, tumour and treatment characteristics, such as histology, TNM classification [36] and BT implant characteristics, were collected. No patient had positive lymph nodes or distant metastases at diagnosis.

\section{Treatment characteristics}

The clinical target volume (CTV), corresponding to the visible gross tumour volume (GTV) plus a safety margin of 5-10 mm, was marked by the radiation oncologist. In all cases, an ocular tungsten shield (CIVCO Medical Solutions) was used to reduce the dose to the eye. The custom-made mould was manually built from impressions of the tumour surface for each patient using conventional thermoplastic material and standard plastic catheters embedded and/or attached on the mask surface. The number of tubes and the distance between them depended on the size of the CTV (Figure 1).

A CT scan with the applicator in situ with dummies inserted in each plastic tube and a thin metallic wire to replicate the drawn skin area (CTV) surface of the mould was performed using $2.5 \mathrm{~mm}$ slice thickness.

Images were sent to the planning system for 3D treatment calculation (Oncentra Masterplan Brachy Planning, Nucletron Elekta); the CTV and the surrounding organs at risk (eyeballs, lens and optic nerves) were contoured on CT slices to obtain the optimized dose distribution.

Fractionated HDR-BT was administered using a dedicated afterloader with a single radioactive source of iridium-192 ( ${ }^{192} \mathrm{Ir}$ ) (microSelectron, Nucletron Elekta).

Before the administration of each treatment fraction, the radiation therapist and the radiation oncologist placed a dedicated ocular shield under the eyelid after local anaesthesia (oxybuprocaine, eye drops) and assessed the accurate repositioning of the mould.

\section{Evaluation}

Patients were reviewed after treatment to evaluate the efficacy (local control - LC) and toxicity of the procedure
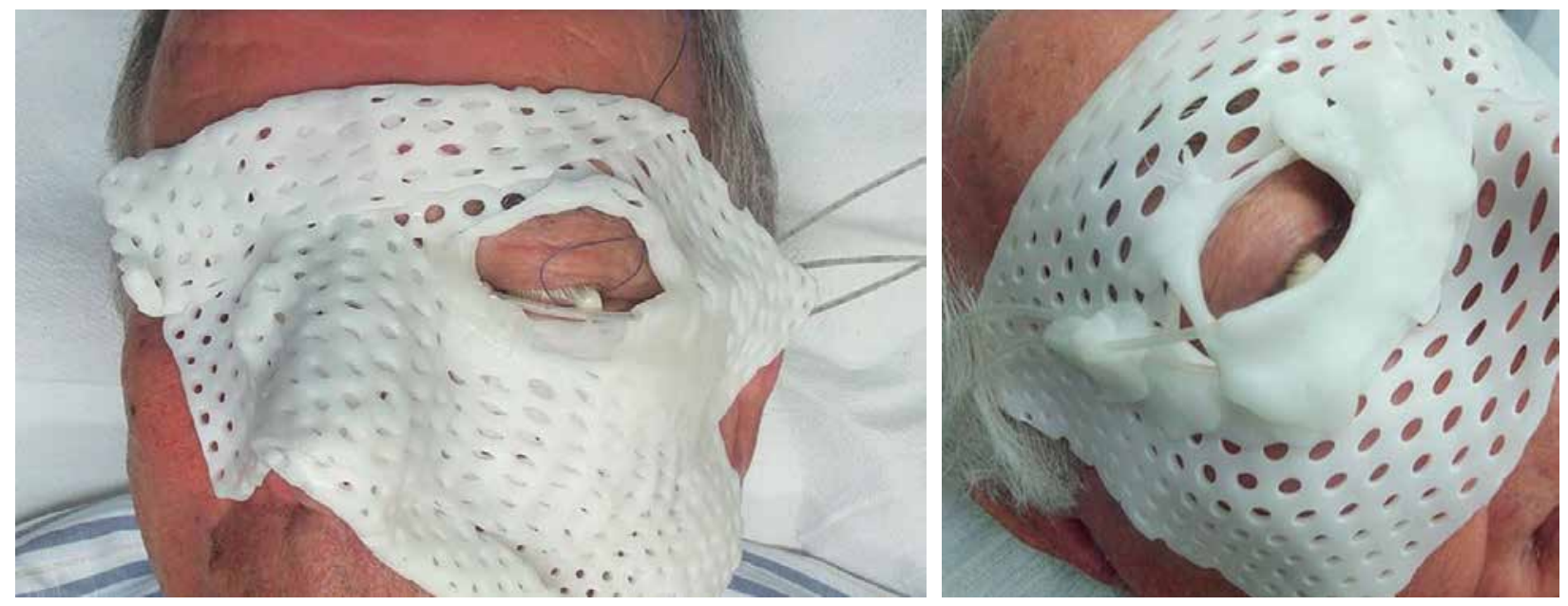

Fig. 1. Custom-made moulds for treatment of eyelid tumour 
every 3-6 months for the first year, every 6 months for the following four years and then annually after 5 years.

During the follow-up period, a routine annual ophthalmic examination was performed to assess any vision impairment and/or eyelid complication.

Acute and late side effects were classified according to the Radiation Therapy Oncology Group (RTOG) and the European Organization for Research and Treatment of Cancer (EORTC) scale. Follow-up time and local control (LC) was considered from the end of BT to the date of the last evaluation. Overall survival (OS) was calculated from the start of BT to the time of death from any cause.

\section{Results}

Between April 2010 and August 2017, 10 consecutive patients with eyelid tumours underwent superficial HDR-BT by custom-made surface mould. One patient was excluded from the analysis because of the absence of written informed consent for the use of anonymized data for research. Therefore, the final cohort of this study included 9 patients (Table 1 ).

Median age was 68 years (range, 31-88 years). According to the $8^{\text {th }}$ TNM-UICC staging system, all lesions were stage I and less of $2 \mathrm{~mm}$ thick. Basal cell and sebaceous gland carcinomas were reported in 5 and 2 patients, respectively; other histological types were non-Hodgkin lymphoma and plasmacytoma.

Median delivered dose to CTV was 42 Gy (30-48 Gy) with a median dose per fraction of 3.5 Gy (2-4.5 Gy) in a median of 12 fractions (10-17) over a median of 16 days (range, 11-71 days). The lower doses were used for the patients with non-Hodgkin lymphoma and plasmacytoma (Figure 2).

The median minimum dose covering $90 \%$ CTV $\left(D_{90}\right)$ was $96 \%(76-104 \%)$. Median CTV volume was $0.91 \mathrm{~cm}^{3}$ $\left(0.3-3.2 \mathrm{~cm}^{3}\right)$. The median and range of the maximum calculated doses $\left(\mathrm{D}_{3 \mathrm{cc}}\right.$ dose to $\left.0.03 \mathrm{~cm}^{3}\right)$ for ipsilateral lens, ipsilateral eye and optical nerve were 35.7 Gy (18.6-40.3 Gy), 42.2 Gy (29.1-56 Gy) and 10.9 Gy (3.9-13.4 Gy), respectively. We assume that these doses were significantly lower due to the use of the dedicated ocular shield, whose presence is not taken into account by the treatment planning system.

Another aim in treatment planning was to limit the maximum dose to the skin surface to $140 \%$ of the prescribed dose [17].

In all cases but one, the treatment tolerance was excellent, without any severe procedural complications. All patients developed acute toxicity during/at the end

Table 1. Characteristics of 9 patients treated with superficial high-dose-rate brachytherapy

\begin{tabular}{|c|c|c|c|c|c|c|c|c|c|}
\hline Pt & $\begin{array}{l}\text { Age at } \\
\text { time of } \\
\text { treatment } \\
\text { (years) }\end{array}$ & Sex & $\begin{array}{l}\text { Site of } \\
\text { tumour }\end{array}$ & Histology & BT dose & $\begin{array}{l}\text { Maximum } \\
\text { acute RTOG } \\
\text { toxicity } \\
\text { (grade) }\end{array}$ & $\begin{array}{c}\text { Maximum late RTOG } \\
\text { toxicity } \\
\text { (grade) }\end{array}$ & $\begin{array}{l}\text { Follow-up } \\
\text { (months) }\end{array}$ & LC \\
\hline 1 & 77 & F & Lower lid & $\mathrm{BCC}$ & $\begin{array}{c}45 \mathrm{~Gy} \text { in } 10 \mathrm{fr} \\
(4.5 \mathrm{~Gy} / \mathrm{fr})\end{array}$ & $\begin{array}{c}1 \\
\text { erythema, } \\
\text { conjunctivitis }\end{array}$ & $\begin{array}{c}1 \text { hyperpigmentation, } \\
\text { epilation }\end{array}$ & 90 & $100 \%$ \\
\hline 2 & 31 & $F$ & Lower lid & $\mathrm{NHL}$ & $\begin{array}{c}34 \mathrm{~Gy} \text { in } 17 \mathrm{fr} \\
(2 \mathrm{~Gy} / \mathrm{fr})\end{array}$ & $\begin{array}{c}2 \\
\text { erythema, } \\
\text { oedema }\end{array}$ & dry eye, hyperpigmentation & 88 & $100 \%$ \\
\hline 3 & 70 & $F$ & Upper lid & SGC & $\begin{array}{l}42 \mathrm{~Gy} \text { in } 12 \mathrm{fr} \\
(3.5 \mathrm{~Gy} / \mathrm{fr})\end{array}$ & $\begin{array}{c}1 \\
\text { erythema, } \\
\text { oedema }\end{array}$ & 0 & 54 & $100 \%$ \\
\hline 4 & 41 & M & Upper lid & Pla & $\begin{array}{l}30 \mathrm{~Gy} \text { in } 12 \mathrm{fr} \\
(2.5 \mathrm{~Gy} / \mathrm{fr})\end{array}$ & $\begin{array}{c}1 \\
\text { erythema, } \\
\text { conjunctivitis }\end{array}$ & 0 & 61 & $100 \%$ \\
\hline 5 & 66 & M & $\begin{array}{l}\text { Lower lid } \\
+ \text { inner } \\
\text { canthus }\end{array}$ & $\mathrm{BCC}$ & $\begin{array}{l}48 \text { Gy in } 16 \mathrm{fr} \\
(3.6 \mathrm{~Gy} / \mathrm{fr})\end{array}$ & $\begin{array}{c}2 \\
\text { erythema }\end{array}$ & $\begin{array}{c}1 \\
\text { cutaneous retraction, } \\
\text { epilation }\end{array}$ & 51 & $100 \%$ \\
\hline 6 & 87 & F & $\begin{array}{l}\text { Lower }+ \\
\text { upper lid }\end{array}$ & SGC & $\begin{array}{l}42 \mathrm{~Gy} \text { in } 12 \mathrm{fr} \\
(3.5 \mathrm{~Gy} / \mathrm{fr})\end{array}$ & $\begin{array}{c}3 \\
\text { erythema }\end{array}$ & $\begin{array}{c}2 \\
\text { moderate corneal ulceration }\end{array}$ & 39 & $100 \%$ \\
\hline 7 & 88 & M & Lower lid & $\mathrm{BCC}$ & $\begin{array}{l}42 \mathrm{~Gy} \text { in } 12 \mathrm{fr} \\
(3.5 \mathrm{~Gy} / \mathrm{fr})\end{array}$ & $\begin{array}{c}1 \\
\text { erythema, } \\
\text { conjunctivitis }\end{array}$ & $\begin{array}{c}1 \\
\text { dry eye }\end{array}$ & 27 & $100 \%$ \\
\hline 8 & 61 & $F$ & Lower lid & $B C C$ & $\begin{array}{l}42 \mathrm{~Gy} \text { in } 12 \mathrm{fr} \\
(3.5 \mathrm{~Gy} / \mathrm{fr})\end{array}$ & $\begin{array}{c}1 \\
\text { erythema, } \\
\text { conjunctivitis }\end{array}$ & 0 & 16 & $100 \%$ \\
\hline 9 & 80 & M & Lower lid & $B C C$ & $\begin{array}{c}42 \mathrm{~Gy} \text { in } 12 \mathrm{fr} \\
(3.5 \mathrm{~Gy} / \mathrm{fr})\end{array}$ & $\begin{array}{c}1 \\
\text { erythema, } \\
\text { conjunctivitis }\end{array}$ & 0 & 20 & $100 \%$ \\
\hline
\end{tabular}

BCC - basal cell carcinoma, SGC - sebaceous carcinoma, NHL - non-Hodgkin lymphoma, Pla-plasmocytoma, LC - local control 

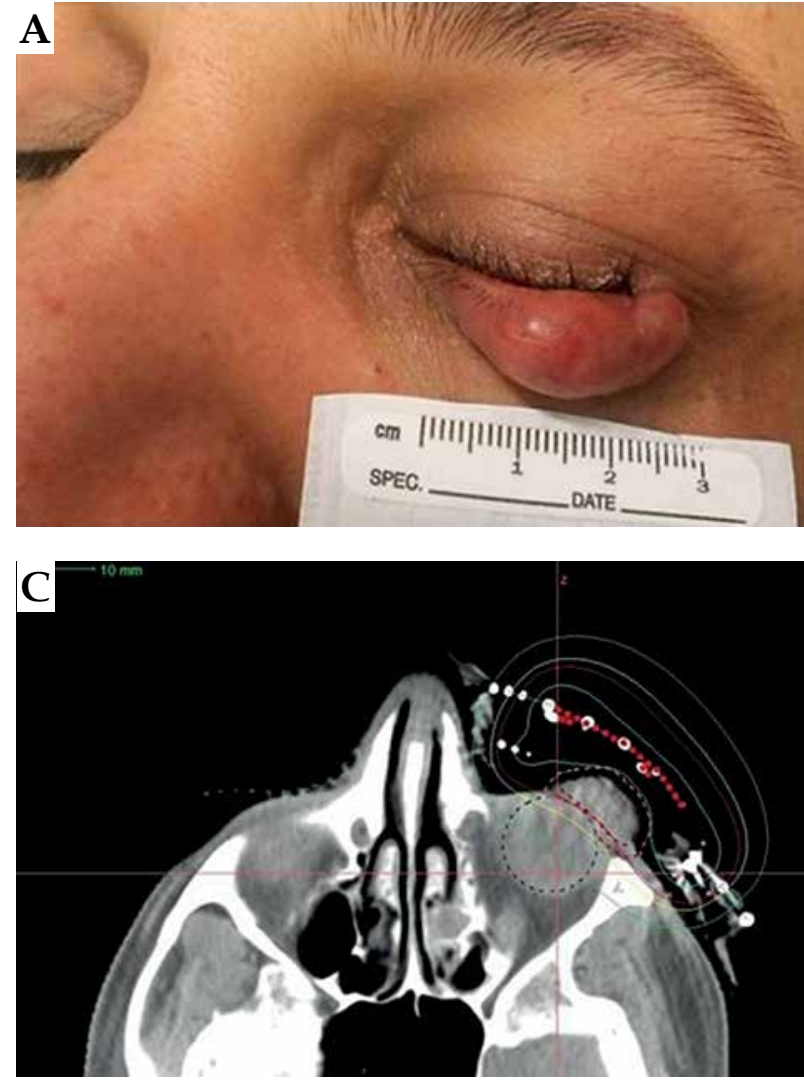

of RT treatment. Acute toxicity reported concerned the conjunctiva and the adjacent skin (e.g. erythema and epilation): 6, 2 and 1 patients showed grade (G) 1, 2 and 3 adverse events respectively. Due to acute G2 conjunctivitis and G3 periorbital erythema, one patient temporarily interrupted treatment.

Results on late toxicity were available for all patients. Four patients did not have any late adverse event; G1 late toxicity (e.g. dry eye or skin alterations such as hyperpigmentation) was reported in 4 patients. One patient (patient no. 6; SGc of both lids; total dose 42 Gy, 3.5 Gy/ fraction) developed a small corneal ulceration (G2) after one year from the end of BT. Maximum calculated doses for ipsilateral lens and eye were $35 \mathrm{~Gy}$ and $44 \mathrm{~Gy}$, respectively and CTV volume was $0.88 \mathrm{~cm}^{3}$. She received only topical agents because the grade and extension of the ulcer did not warrant ocular surgery. No patients developed optic neuropathy or retinopathy, epiphora or vision impairment. After a median follow-up of 51 months (16-90 months), all patients were alive (OS $100 \%)$. No patient was lost to follow-up or had a clear evidence of local recurrence. No lymphatic or distant metastases were recorded. Cosmetic results were considered good in all cases.

\section{Discussion}

Surgery is the standard of care for non-melanoma skin cancer, including eyelid tumours. Many factors may influence the therapeutic choice and a multidisciplinary approach is mandatory.

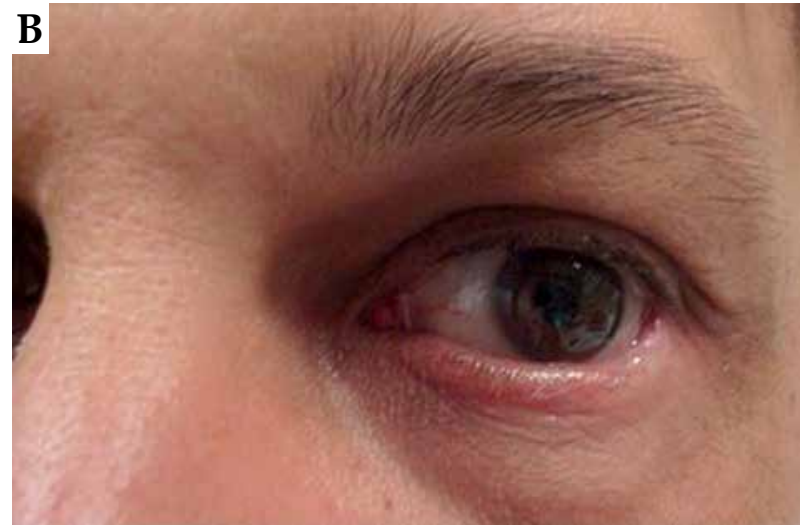

Fig. 2. Plasmacytoma of the lower eyelid before (A) and 40 months after (B) HDR-BT. CT-based planning of HDR-BT treatment $(\mathbf{C})$

Since the aim of treatment is definitive tumour control with functional preservation of anatomical structures, EBRT and BT could be good alternatives to surgery in selected cases, especially for non-operable patients (medical contraindications or patient refusal) and for those patients with lesions at high risk of poor functional results after surgery.

To the best of our knowledge, there is only one randomized trial (published in 1997) comparing RT vs. surgery in patients with BCC of the face. BCC of the eyelid represents $20 \%$ of the RT group and three radiation techniques were used: interstitial BT, superficial BT and conventional EBRT. Outcome and cosmetic results were significantly better after surgery than after RT, whatever modality. No analysis of outcomes with regards to the RT technique was performed [37].

There are only a few studies available in the literature regarding the use of BT in eyelid tumour. In all of these reports, the cohorts of patients were very heterogeneous in terms of histology, treatment aims (adjuvant vs. curative BT), type of BT (LDR vs. HDR) and total dose. Acute and late toxicity are not always well discussed and data on toxicity frequencies are often lacking.

In 2015, a systematic review analysed six publications, concluding that BT has a high rate of local control (median 95.2\%) with acceptable toxicity and a good functional-cosmetic outcome [15].

The most frequent acute toxicities reported were oedema and conjunctival erythema. Late toxicities reported in individual studies were unilateral cataract, entropion, conjunctivitis, eyelid malocclusion, epiphora and corneal ulcer. 
Table 2. Overview of relevant publications on high-dose-rate brachytherapy

\begin{tabular}{|c|c|c|c|c|c|c|c|c|}
\hline Study & $\begin{array}{l}\text { Number of } \\
\text { patients }\end{array}$ & Site & Histology & Modality & $\begin{array}{c}\text { Total dose } \\
\text { and fractions }\end{array}$ & $\begin{array}{l}\text { Median } \\
\text { follow-up, } \\
\text { months } \\
\text { (range) }\end{array}$ & Local control & $\begin{array}{c}\text { Good } \\
\text { cosmetic } \\
\text { outcome }\end{array}$ \\
\hline $\begin{array}{l}\text { Martinez- } \\
\text { Monge et al. } \\
\text { [29] }\end{array}$ & 1 & Lower & SCC & $\begin{array}{l}\text { Adjuvant IBT } \\
\text { bid }\end{array}$ & 32 Gy/4 & 6 & $100 \%$ & $100 \%$ \\
\hline $\begin{array}{l}\text { Azad et al. } \\
\text { [30] }\end{array}$ & 20 & $\begin{array}{l}\text { Lower: } 11 \\
\text { Upper: } 9\end{array}$ & $\begin{array}{l}\text { SCC: } 50 \% \\
\text { SGC: } 40 \% \\
\text { BCC: } 10 \%\end{array}$ & IBT & 39 Gy/6 & $\begin{array}{c}39.5 \\
(18-72)\end{array}$ & $\begin{array}{l}75.6 \% \\
\text { at } 5 \text { years }\end{array}$ & $100 \%$ \\
\hline $\begin{array}{l}\text { Laskar et al. } \\
\text { [31] }\end{array}$ & 8 & $\begin{array}{l}\text { Lower: } 5 \\
\text { Upper: } 3\end{array}$ & $\begin{array}{l}\text { BCC: } 12.5 \% \\
\text { SCC: } 37.5 \% \\
\text { SGc: } 50 \%\end{array}$ & $\begin{array}{l}\text { Adjuvant IBT } \\
\text { bid }\end{array}$ & $\begin{array}{l}21 \mathrm{~Gy} / 7 \\
35 \mathrm{~Gy} / 10\end{array}$ & $\begin{array}{c}34.5 \\
\text { One lost to } \\
\text { follow-up }\end{array}$ & $100 \%$ & $100 \%$ \\
\hline $\begin{array}{l}\text { Mareco et al. } \\
\text { [32] }\end{array}$ & 17 & $\begin{array}{l}\text { Lower: } 15 \\
\text { Upper: } 1 \\
\text { Inner } \\
\text { canthus: } 1\end{array}$ & $\begin{array}{l}\text { BCC: } 94 \% \\
\text { SCC: } 6 \%\end{array}$ & $\begin{array}{l}\text { IBT } \\
\text { bid }\end{array}$ & 32-50 Gy/9-11 & $\begin{array}{c}40 \\
(7-43)\end{array}$ & $94.1 \%$ & $70 \%$ \\
\hline Guix et al. [23] & $\begin{array}{c}16 \\
\text { Other site } \\
\text { of face: } \\
120\end{array}$ & - & BCC: $100 \%$ & CBT & 60-65 Gy/33-36 & - & $100 \%$ & $100 \%$ \\
\hline $\begin{array}{l}\text { Franco et al. } \\
{[25]}\end{array}$ & 1 & Lower & $\begin{array}{l}\text { Mantle cell } \\
\text { lymphoma }\end{array}$ & CBT & 30 Gy/20 daily & 36 & $100 \%$ & - \\
\hline $\begin{array}{l}\text { Montero et al. } \\
{[24]}\end{array}$ & 2 & - & BCC: $100 \%$ & CBT & 44-48 Gy/11-12 & $\begin{array}{c}15 \\
(4-36)\end{array}$ & $100 \%$ & - \\
\hline $\begin{array}{l}\text { DeSimone } \\
\text { et al. [27] }\end{array}$ & 1 & $\begin{array}{c}\text { Bilateral } \\
\text { eyelids }\end{array}$ & $\begin{array}{l}\text { T-cell lym- } \\
\text { phoma }\end{array}$ & CBT & 8 Gy/2 daily & - & $100 \%$ & $100 \%$ \\
\hline Our study & 9 & $\begin{array}{l}\text { Lower: } 7 \\
\text { Upper: } 1 \\
\text { Both: } 1\end{array}$ & $\begin{array}{l}\text { BCC: } 56 \% \\
\text { SGc: } 22 \% \\
\text { NHL: } 11 \% \\
\text { Pla: } 11 \%\end{array}$ & CBT & 30-48 Gy/10-17 & $\begin{array}{c}51 \\
(16-90)\end{array}$ & $100 \%$ & $100 \%$ \\
\hline
\end{tabular}

BCC-basal cell carcinoma, SCC-squamous cell carcinoma, SGC-sebaceous gland carcinoma, NHL-non-Hodgkin lymphoma, Pla-plasmocytoma, Bid-bis in die, 2 fractions/day, IBT - interstitial brachytherapy, CBT - contact brachytherapy with custom-made mould, LC - local control

In a recent meta-analysis published in 2018 , the reported outcomes of skin cancers did not exhibit a significant difference between EBRT and BT in terms of local control, though the authors observed a significant benefit of BT over EBRT concerning cosmesis and functional outcome [20].

Limitations of this study include the monocentric and retrospective analysis and the low number of lesions treated, due to the infrequent presentation site of disease.

However, our data support the concept that HDR-BT for the treatment of eyelid cancer is feasible and effective with acceptable complications comparing very favourably with other published reports in the literature (Table 2). In our cohort, no patients developed a local recurrence with a local control rate of $100 \%$ after a median follow-up time of 51 months. According to other publications, our treatment was well tolerated: most patients (89\%) developed low-grade (G1-G2) acute toxicity concerning especially eyelid and surrounding skin and conjunctiva. Late adverse events regarded G1 skin pigmentation changes or epilation (33\% of cases), but the aesthetic outcome was considered satisfactory by $100 \%$ of patients, consistent with the outcomes of other reports on HDR-BT. Acute G3 and late G2 toxicities were medically treated, without the need of surgery and without resulting in functional impairment or blindness.

The use of advanced techniques, in particular 3D printer technology, is under investigation in order to improve the quality of treatments and the therapeutic and aesthetic outcome $[38,39]$.

\section{Conclusions}

In this study, we analysed toxicity, survival and disease control in eyelid cancer patients treated with HDRBT. Evidence from studies comparing the results of BT with other treatments is lacking in the literature. We support the concept that HDR-BT with mould applicators can deliver an effective alternative treatment technique to other RT modalities for the treatment of eyelid carcinoma. Our study shows a very good rate of disease control (LC 100\%) with an acceptable toxicity profile (only one case of G3 late toxicity without sequelae).

\section{Disclosure}

The authors report no conflict of interest. 


\section{References}

1. Petsuksiri J, Frank SJ, Garden AS et al. Outcomes after radiotherapy for squamous cell carcinoma of the eyelid. Cancer 2008; 112: 111-118.

2. Deprez M, Uffer S. Clinicopathological features of eyelid skin tumors. A retrospective study of 5504 cases and review of literature. Am J Dermatopathol 2009; 31: 256-262.

3. Silverman N, Shinder R. What's new in eyelid tumors. Asia Pac J Ophthalmol 2017; 6: 143-152.

4. Saleh GM, Desai P, Collin JR et al. Incidence of eyelid basal cell carcinoma in England: 2000-2010. Br J Ophthalmol 2017; 101: 209-212.

5. Yu SS, Zhao Y, Zhao H et al. A retrospective study of 2228 cases with eyelid tumors. Int J Ophthalmol 2018; 11: 1835-1841.

6. Cook BE Jr, Bartley GB. Treatment options and future prospects for the management of eyelid malignancies: an evidence-based update. Ophthalmology 2001; 108: 2088-2098.

7. Mosterd K, Krekels GA, Nieman FH et al. Surgical excision versus Mohs' micrographic surgery for primary and recurrent basal-cell carcinoma of the face: a prospective randomised controlled trial with 5-years' follow-up. Lancet Oncol 2008; 9: 1149-1156.

8. Murchison AP, Walrath JD, Washington CV. Non-surgical treatments of primary, non-melanoma eyelid malignancies: a review. Clin Exp Ophthalmol 2011; 39: 65-83.

9. Yin VT, Merritt HA, Sniegowski M et al. Eyelid and ocular surface carcinoma: diagnosis and management. Clin Dermatol 2015; 33: 159-169.

10. Phan K, Loya A. Mohs micrographic surgery versus wide local excision for sebaceous adenocarcinoma of the eyelid: Analysis of a national database. J Plast Reconstr Aesthet Surg 2019; 72: 1007-1101.

11. Nag S, Cano ER, Demanes DJ et al., American Brachytherapy Society. The American Brachytherapy Society recommendations for high-dose-rate brachytherapy for head-and-neck carcinoma. Int J Radiat Oncol Biol Phys 2001; 50: 1190-1198.

12. Alam M, Nanda S, Mittal BB et al. The use of brachytherapy in the treatment of nonmelanoma skin cancer: a review. J Am Acad Dermatol 2011; 65: 377-388.

13. Hata M, Koike I, Maegawa J et al. Radiation therapy for primary carcinoma of the eyelid: tumor control and visual function. Strahlenther Onkol 2012; 188: 1102-1107.

14. Aronow ME, Singh AD. Radiation therapy: conjunctival and eyelid tumors. Dev Ophthalmol 2013; 52: 85-93.

15. Frakulli R, Galuppi A, Cammelli $S$ et al. Brachytherapy in non-melanoma skin cancer of eyelid: a systematic review. J Contemp Brachytherapy 2015; 7: 497-502.

16. Skowronek J. Brachytherapy in the treatment of skin cancer: an overview. Postepy Derm Alergol 2015; 32: 362-367.

17. Ouhib Z, Kasper M, Perez Calatayud J et al. Aspects of dosimetry and clinical practice of skin brachytherapy: The American Brachytherapy Society working group report. Brachytherapy 2015; 14: 840-858.

18. Delishaj D, Rembielak A, Manfredi B et al. Non-melanoma skin cancer treated with high-dose-rate brachytherapy: a review of literature. I Contemp Brachytherapy 2016; 8: 533-540.

19. Likhacheva AO, Devlin PM, Shirvani SM et al. Skin surface brachytherapy: A survey of contemporary practice patterns. Brachytherapy 2017; 16: 223-229.

20. Zaorsky NG, Lee CT, Zhang E et al. Skin CanceR Brachytherapy vs External beam radiation therapy (SCRiBE) meta-analysis. Radiother Oncol 2018; 126: 386-393.

21. Mierzwa ML. Radiotherapy for skin cancers of the face, head and neck. Facial Plast Surg Clin North Am 2019; 27: 131-138.

22. Guinot JL, Rembielak A, Perez-Calatayud J et al. GEC-ESTRO ACROP recommendations in skin brachytherapy. Radiother Oncol 2018; 126: 377-385.
23. Guix B, Finestres F, Tello JI et al. Treatment of skin carcinomas of the face by High-Dose-Rate brachytherapy and custom-made surface molds. Int J Radiat Oncol Biol Phys 2000; 47: 95-102.

24. Montero A, Hernanz R, Capuz AB et al. High-dose-rate (HDR) plesiotherapy with custom-made moulds for the treatment of non-melanoma skin cancer. Clin Transl Oncol 2009; 11: 760-764

25. Franco P, Filippi AR, Ricca I et al. Eyelid localization in mantle cell lymphoma: long-lasting complete remission after surface brachytherapy. Tumori 2009; 95: 385-388.

26. Kowalik L, Lyczek J, Sawicki M et al. Individual applicator for brachytherapy for various sites of superficial malignant lesions. J Contemp Brachytherapy 2013; 5: 45-49.

27. DeSimone JA, Guenova E, Carter JB et al. Low-dose highdose-rate brachytherapy in the treatment of facial lesions of cutaneous T-cell lymphoma. J Am Acad Dermatol 2013; 69: 61-65.

28. Jumeau R, Renard-Oldrini S, Courrech F et al. High dose rate brachytherapy with customized applicators for malignant facial skin lesions. Cancer Radiother 2016; 20: 341-346.

29. Martínez-Monge R, Gómez-Iturriaga A. High-dose-rate brachytherapy in lower eyelid cancer. Brachytherapy 2007; 6: 227-229.

30. Azad S, Choudhary V. Treatment results of high dose rate interstitial brachytherapy in carcinoma of eye lid. J Can Res Ther 2011; 7: 157-161.

31. Laskar SG, Basu T, Chaudhary S et al. Postoperative interstitial brachytherapy in eyelid cancer: long term results and assessment of Cosmesis After Interstitial Brachytherapy scale. J Contemp Brachytherapy 2015; 6: 350-355.

32. Mareco V, Bujor L, Abrunhosa-Branquinho AN et al. Interstitial high-dose-rate brachytherapy in eyelid cancer. Brachytherapy 2015; 14: 554-564.

33. Kasper ME, Chaudhary AA. Novel treatment options for nonmelanoma skin cancer: focus on electronic brachytherapy. Med Devices (Auckl) 2015; 8: 493-502.

34. Eftekhari K, Anderson RL, Suneja G et al. Local recurrence and ocular adnexal complications following electronic surface brachytherapy for basal cell carcinoma of the lower eyelid. JAMA Dermatol 2015; 151: 1002-1004.

35. Delishaj D, Laliscia C, Manfredi B et al. Non-melanoma skin cancer treated with high-dose-rate brachytherapy and Valencia applicator in elderly patients: a retrospective case series. J Contemp Brachytherapy 2015; 7: 437-444.

36. Brierley JD, Gospodarowicz MK, Wittekind C. TNM Classification of Malignant Tumours. $8^{\text {th }}$ ed. November 2016.

37. Avril MF, Auperin A, Margulis A et al. Basal cell carcinoma at the face: surgery or radiotherapy? Results of a randomized study. Br J Cancer 1997; 76: 100-106.

38. Ricotti R, Vavassori A, Bazani A et al. 3D-printed applicators for high dose rate brachytherapy: Dosimetric assessment at different infill percentage. Phys Med 2016; 32: 1698-1706.

39. Jones EL, Tonino Baldion A, Thomas C et al. Introduction of novel 3D-printed superficial applicators for high-dose-rate skin brachytherapy. Brachytherapy 2017; 16: 409-414. 